\title{
Delayed Improvement of Left Ventricular Function in Newly Diagnosed Heart Failure Depends on Etiology-A PROLONG-II Substudy
}

\author{
Johanna Mueller-Leisse (D), Johanna Brunn, Christos Zormpas, Stephan Hohmann (D, \\ Henrike Aenne Katrin Hillmann, Jörg Eiringhaus, Johann Bauersachs, Christian Veltmann ${ }^{\dagger}$ \\ and David Duncker *,+ (D)
}

check for

updates

Citation: Mueller-Leisse, J.; Brunn, J. Zormpas, C.; Hohmann, S.; Hillmann, H.A.K.; Eiringhaus, J.; Bauersachs, J.; Veltmann, C.; Duncker, D. Delayed Improvement of Left Ventricular Function in Newly Diagnosed Heart Failure Depends on Etiology-A PROLONG-II Substudy. Sensors 2022, 22, 2037. https://doi.org/10.3390/ s22052037

Academic Editor: Ki H. Chon

Received: 19 January 2022

Accepted: 1 March 2022

Published: 5 March 2022

Publisher's Note: MDPI stays neutra with regard to jurisdictional claims in published maps and institutional affiliations.

Copyright: (C) 2022 by the authors. Licensee MDPI, Basel, Switzerland. This article is an open access article distributed under the terms and conditions of the Creative Commons Attribution (CC BY) license (https:// creativecommons.org/licenses/by/ $4.0 /)$.
Hannover Heart Rhythm Center, Department of Cardiology and Angiology, Hannover Medical School, Carl-Neuberg-Str. 1, 30625 Hannover, Germany; mueller-leisse.johanna@mh-hannover.de (J.M.-L.); johanna@brunn-online.net (J.B.); zormpas@vinzenzkrankenhaus.de (C.Z.); hohmann.stephan@mh-hannover.de (S.H.); hillmann.henrike@mh-hannover.de (H.A.K.H.); eiringhaus.joerg@mh-hannover.de (J.E.); bauersachs.johann@mh-hannover.de (J.B.); c.veltmann@ep-bremen.com (C.V.)

* Correspondence: duncker.david@mh-hannover.de; Tel.: +49-511-532-82604

t These authors contributed equally to this work.

\begin{abstract}
In patients with newly diagnosed heart failure with reduced ejection fraction (HFrEF), three months of optimal therapy are recommended before considering a primary preventive implantable cardioverter-defibrillator (ICD). It is unclear which patients benefit from a prolonged waiting period under protection of the wearable cardioverter-defibrillator (WCD) to avoid unnecessary ICD implantations. This study included all patients receiving a WCD for newly diagnosed HFrEF $(n=353)$ at our center between 2012 and 2017. Median follow-up was 2.7 years. From baseline until three months, LVEF improved in patients with all peripartum cardiomyopathy (PPCM), myocarditis, dilated cardiomyopathy (DCM), or ischemic cardiomyopathy (ICM). Beyond this time, LVEF improved in PPCM and DCM only (10 $\pm 8 \%$ and $10 \pm 12 \%$, respectively), whereas patients with ICM showed no further improvement. The patients with newly diagnosed HFrEF were compared to 29 patients with a distinct WCD indication, which is an explantation of an infected ICD. This latter group had a higher incidence of WCD shocks and poorer overall survival. All-cause mortality should be considered when deciding on WCD prescription. In patients with newly diagnosed HFrEF, the potential for delayed LVEF recovery should be considered when timing ICD implantation, especially in patients with PPCM and DCM.
\end{abstract}

Keywords: HFrEF; heart failure; WCD (wearable cardioverter-defibrillator); ICD (implantable cardioverterdefibrillator); LVEF (left ventricular ejection fraction); SCD (sudden cardiac death); PPCM (peripartum cardiomyopathy)

\section{Introduction}

Patients with newly diagnosed heart failure with reduced ejection fraction (HFrEF) are at risk of sudden cardiac death [1-4]. In the current guidelines, a primary preventive implantable cardioverter-defibrillator (ICD) is indicated to prevent sudden cardiac death in these patients, if left ventricular ejection fraction (LVEF) remains reduced after three months of optimized heart failure therapy [5]. However, modern heart failure therapy has led to an improved prognosis for HFrEF patients, and a reduction in both sudden and non-sudden deaths [6-8]. Meanwhile, complication rates of ICD therapy remain non-negligible [9-11]. Despite this, a large percentage of ICD implantations performed are non-indicated [12]. Therefore, thorough risk stratification to avoid unnecessary ICD implantations is crucial [13-16]. In the PROLONG study, extending the time of therapy optimization beyond three months under the protection 
of the wearable cardioverter-defibrillator (WCD) to await further LVEF improvement in some patients with newly diagnosed HFrEF has been proposed [13]. However, which patients benefit from such prolonged risk stratification is unclear $[3,17]$. WCD prescription and the timing of ICD implantation remain controversial, and further data on LVEF recovery potential and long-term prognosis are warranted [14,15,18,19]. Furthermore, the WCD has been criticized for its high cost and no proven survival benefit in a randomized controlled trial [20-22]. In the PROLONG-II study, it was shown that overall survival after the WCD was favorable, including in patients after a WCD shock. These results argued against a mere mortality shift from sudden to non-sudden deaths by the WCD [23]. The aim of the present analysis was to evaluate the potential for LVEF improvement, and the incidence of early and late life-threatening arrhythmias and mid-term mortality in different entities of HFrEF. We also compared the outcomes of patients with newly diagnosed HFrEF with patients receiving the WCD after explantation of a previously implanted ICD. Explantation of an infected ICD is another indication for the WCD, which seems less controversial compared to the indication in newly diagnosed HFrEF [24-26]. However, proof of an overall long-term survival benefit in this patient group is also lacking, and data on long-term follow-up and prognosis are warranted [27].

\section{Methods}

The PROLONG-II study was an observational single-center study evaluating the prognosis of patients with HFrEF after WCD prescription. Detailed trial design has been described elsewhere [23]. In brief, patients receiving a WCD (LifeVest, Zoll, Pittsburgh, PA, USA) for newly diagnosed HFrEF at Hannover Medical School between 2012 and 2017 were included. WCD prescription time was at minimum three months, but was extended in patients with newly diagnosed HFrEF when further LVEF improvement was anticipated to avoid unnecessary ICD implantations, according to previously described criteria from the PROLONG study. Borderline LVEF value at three months (30-35\%) marked an increase in LVEF compared to baseline ( $\geq 5 \%)$ and nonoptimized heart failure therapy [13].

The present study also analyzed a second, distinct patient cohort consisting of patients receiving the WCD after an explanted ICD during the same time period.

The study complies with the Declaration of Helsinki and was approved by the local ethics committee. All patients gave informed consent.

Data including clinical status and clinical history, medication, basic laboratory parameters, electrocardiograms, left ventricular function in echocardiography, and/or cardiac magnetic resonance imaging and WCD data, including wear time and arrhythmic episodes, were acquired at baseline, at three months, and at last available follow-up, and were derived from inpatient visits, outpatient visits and/or telephone interviews, and from the remote monitoring platform of the manufacturer of the WCD. Renal disease was defined as known renal damage, chronic eGFR $<60 \mathrm{~mL} / \mathrm{min} / 1.73$ or acute kidney injury according to KDIGO criteria. WCD therapies occurring in the context of unstable fast ventricular tachycardia (>200 beats per minute) or ventricular fibrillation were considered appropriate. Patients alive at the last available follow-up were labelled as censored.

\section{Statistics}

Statistical analysis was performed using SPSS Statistics version 26 (IBM Corp., Armonk, NY, USA). Continuous variables were reported as median and range or mean with standard deviation. Wilcoxon test, Mann-Whitney U test, Kruskal-Walllis test and Friedman's test were used for associations, as appropriate. Categorical variables were reported as numbers and percentages, and the chi-squared test or binary logistic regression analysis were used for associations. Moreover, $p$-values $<0.05$ were considered statistically significant, after adjustment for multiple testing by Bonferroni correction where appropriate. The first and last authors take full responsibility for data integrity and analysis. 


\section{Results}

\subsection{Baseline Characteristics}

The PROLONG-II study included 353 patients (69\% male; mean age $56 \pm 15$ years) with newly diagnosed HFrEF (mean LVEF $25 \pm 8 \%$ ). HFrEF etiologies were ischemic cardiomyopathy (ICM) in 126 patients (36\%), dilated cardiomyopathy (DCM) in 169 patients $(48 \%)$, peripartum cardiomyopathy (PPCM) in 27 patients $(7 \%)$, myocarditis in 24 patients $(7 \%)$, and other non-ischemic cardiomyopathy including amyloidosis, hypertrophic obstructive cardiomyopathy, and congenital heart disease in seven patients (2\%). Baseline characteristics of the patients are presented in Table 1. Patients with PPCM were younger compared to ICM $(p<0.001)$, DCM $(p<0.001)$ and myocarditis $(p=0.005)$; patients with myocarditis were younger than ICM and DCM patients $(p<0001)$; and patients with DCM were younger than patients with ICM $(p<0.001)$. Baseline LVEF was significantly lower in patients with PPCM and DCM compared to ICM ( $p=0.003$ each). Baseline NYHA functional class was highest in patients with PPCM. Differences in NT-proBNP levels were not statistically significant. Patients with ICM had more cardiovascular risk factors, while patients with DCM more often had renal disease.

Table 1. Baseline characteristics of different HFrEF etiologies.

\begin{tabular}{|c|c|c|c|c|c|c|c|}
\hline & All HFrEF & ICM & DCM & РPCM & Myocarditis & Other & $p$-Value \\
\hline $\begin{array}{c}\text { Patients, } \mathrm{n} \\
(\%)\end{array}$ & $353(100)$ & $126(35)$ & $169(48)$ & $27(7)$ & $24(7)$ & $7(2)$ & \\
\hline Male, n (\%) & 244 (69) & 107 (85) & $118(70)$ & $0(0)$ & $15(63)$ & $4(57)$ & $<0.001$ \\
\hline Age, years & $56 \pm 15$ & $64 \pm 11$ & $56 \pm 14$ & $34 \pm 4$ & $50 \pm 14$ & $47 \pm 17$ & $<0.001$ \\
\hline $\begin{array}{l}\text { LVEF, \% } \\
\text { NYHA }\end{array}$ & $25 \pm 8$ & $27 \pm 8$ & $24 \pm 7$ & $21 \pm 7$ & $23 \pm 9$ & $28 \pm 4$ & $<0.001$ \\
\hline $\begin{array}{l}\text { functional } \\
\text { class }\end{array}$ & $2.7 \pm 0.7$ & $2.7 \pm 0.7$ & $2.6 \pm 0.7$ & $3.2 \pm 0.7$ & $2.8 \pm 0.7$ & $2.3 \pm 0.5$ & 0.008 \\
\hline $\begin{array}{c}\text { NT-proBNP, } \\
\text { ng/L }\end{array}$ & $6549 \pm 8565$ & $5197 \pm 6847$ & $7959 \pm 10,017$ & $5713 \pm 7621$ & $4571 \pm 2865$ & $2455 \pm 2418$ & 0.388 \\
\hline $\begin{array}{l}\text { Heart rate, } \\
\text { bpm }\end{array}$ & $82 \pm 23$ & $80 \pm 19$ & $82 \pm 20$ & $85 \pm 19$ & $89 \pm 45$ & $77 \pm 20$ & 0.646 \\
\hline $\mathrm{AF}, \mathrm{n}(\%)$ & $58(17)$ & $21(17)$ & $33(20)$ & $1(4)$ & $3(13)$ & $0(0)$ & 0.196 \\
\hline $\begin{array}{c}\text { QRS } \\
\text { duration, ms }\end{array}$ & $116 \pm 29$ & $114 \pm 27$ & $118 \pm 31$ & $104 \pm 28$ & $112 \pm 22$ & $118 \pm 23$ & 0.05 \\
\hline LBBB, n (\%) & $65(19)$ & $17(14)$ & $37(22)$ & $6(22)$ & $4(17)$ & $1(14)$ & 0.706 \\
\hline $\begin{array}{l}\text { Pacemaker, } \mathrm{n} \\
(\%)\end{array}$ & $10(3)$ & $6(5)$ & $4(2)$ & $0(0)$ & $0(0)$ & $0(0)$ & 0.474 \\
\hline $\begin{array}{l}\text { Hypertension, } \\
\mathrm{n}(\%)\end{array}$ & $196(56)$ & $98(78)$ & $81(48)$ & $5(19)$ & $10(42)$ & $2(29)$ & $<0.001$ \\
\hline $\begin{array}{c}\text { Diabetes, } \mathrm{n} \\
(\%)\end{array}$ & $81(23)$ & $54(43)$ & $20(12)$ & $2(7)$ & $4(17)$ & $1(14)$ & $<0.001$ \\
\hline $\begin{array}{c}\text { Family } \\
\text { history of } \\
\text { CVD, n }(\%)\end{array}$ & $57(16)$ & $26(21)$ & $23(14)$ & $4(15)$ & $4(17)$ & $0(0)$ & 0.397 \\
\hline $\begin{array}{c}\text { Dyslipidemia, } \\
\text { n (\%) }\end{array}$ & $119(34)$ & $77(61))$ & $37(22)$ & $1(4)$ & $4(17)$ & $0(0)$ & $<0.001$ \\
\hline $\begin{array}{l}\text { Smoking, } \mathrm{n} \\
(\%)\end{array}$ & $157(45)$ & $67(53)$ & $72(43)$ & $5(19)$ & $12(50)$ & $1(14)$ & 0.006 \\
\hline $\begin{array}{c}\text { Alcohol } \\
\text { abuse, n (\%) }\end{array}$ & $6(2)$ & $2(2)$ & $4(2)$ & $0(0)$ & $0(0)$ & $0(0)$ & 0.833 \\
\hline $\begin{array}{c}\text { Renal } \\
\text { disease, } \mathrm{n}(\%)\end{array}$ & $77(22)$ & $24(19)$ & $46(27)$ & $1(4)$ & $4(17)$ & $2(29)$ & 0.056 \\
\hline
\end{tabular}

HFrEF, heart failure with reduced ejection fraction; ICM, ischemic cardiomyopathy; DCM, dilated cardiomyopathy; PPCM, peripartum cardiomyopathy; LVEF, left ventricular ejection fraction; NYHA, New York Heart Association; $\mathrm{AF}$, atrial fibrillation; LBBB, left bundle branch block; CVD, cardiovascular disease.

In addition to the patients with newly diagnosed HFrEF, we also analyzed a second, distinct patient cohort receiving the WCD after explantation of an ICD. This group in- 
cluded 29 patients (86\% male; aged $67 \pm 13$ years). Characteristics of the patients with an explanted ICD compared to patients with newly diagnosed HFrEF are presented in Table 2. Patients with an explanted ICD were significantly older $(p=0.036)$, had higher LVEF values $(p<0.001)$, lower NYHA class $(p=0.002)$ and lower NT-proBNP levels $(p<0.001)$. They had more comorbidities such as diabetes $(p=0.026)$, dyslipidemia $(p<0.001)$ and renal disease $(p=0.005)$. Underlying heart disease of the patients was ICM in 17 (59\%), DCM in seven $(24 \%)$, and other in five $(17 \%)$. ICD indication was the secondary prevention in 13 patients $(45 \%)$.

Table 2. Baseline characteristics of patients with an explanted ICD versus patients with newly diagnosed HFrEF (PROLONG-II cohort).

\begin{tabular}{|c|c|c|c|}
\hline & Explant Cohort & $\begin{array}{l}\text { PROLONG-II } \\
\text { Cohort }\end{array}$ & $p$-Value \\
\hline Patients, n & 29 & 353 & \\
\hline $\begin{array}{l}\text { Underlying heart } \\
\text { disease }\end{array}$ & & & $<0.001$ \\
\hline ICM & $17(59)$ & $126(35)$ & \\
\hline DCM & $7(24)$ & $169(48)$ & \\
\hline PPCM & 0 & $27(7)$ & \\
\hline Myocarditis & 0 & $24(7)$ & \\
\hline Other & $5(17)$ & $7(2)$ & \\
\hline Male, n (\%) & $25(86)$ & $244(69)$ & 0.036 \\
\hline Age, years & $67 \pm 13$ & $56 \pm 15$ & $<0.001$ \\
\hline LVEF, \% & $34 \pm 13$ & $25 \pm 8$ & $<0.001$ \\
\hline $\begin{array}{l}\text { NYHA functional } \\
\text { class }\end{array}$ & $2.2 \pm 0.8$ & $2.7 \pm 0.7$ & 0.002 \\
\hline NT-proBNP, ng/L & $2743 \pm 5462$ & $6549 \pm 8565$ & $<0.001$ \\
\hline Heart rate, bpm & $77 \pm 17$ & $82 \pm 23$ & 0.207 \\
\hline $\mathrm{AF}, \mathrm{n}(\%)$ & $3(10)$ & $58(17)$ & 0.421 \\
\hline QRS duration, ms & $132 \pm 33$ & $116 \pm 29$ & 0.025 \\
\hline LBBB, n (\%) & $4(14)$ & $65(19)$ & 0.787 \\
\hline Hypertension, n (\%) & $19(66)$ & $196(56)$ & 0.297 \\
\hline Diabetes, n (\%) & $12(41)$ & $81(23)$ & 0.026 \\
\hline $\begin{array}{c}\text { Family history of } \\
\text { CVD, } \\
\mathrm{n}(\%)\end{array}$ & $5(17)$ & $57(16)$ & 0.878 \\
\hline Dyslipidemia, n (\%) & $19(66)$ & $119(34)$ & 0.001 \\
\hline Smoking, n (\%) & $15(52)$ & $157(45)$ & 0.451 \\
\hline Alcohol abuse, n (\%) & $1(3)$ & $6(2)$ & 0.5 \\
\hline Renal disease, $\mathrm{n}(\%)$ & $13(45)$ & $77(22)$ & 0.005 \\
\hline
\end{tabular}

ICM, ischemic cardiomyopathy; DCM, dilated cardiomyopathy; PPCM, peripartum cardiomyopathy; LVEF, left ventricular ejection fraction; NYHA, New York Heart Association; AF, atrial fibrillation; LBBB, left bundle branch block; CVD, cardiovascular disease.

\subsection{Follow-Up}

Follow-up of patients with newly diagnosed HFrEF was $2.8 \pm 1.5$ years $(2.9 \pm 1.6$ for ICM patients, $2.7 \pm 1.5$ for DCM, $3.2 \pm 1.5$ for PPCM, $2.4 \pm 1.3$ for myocarditis and $2.9 \pm 1.6$ for others). Twenty patients were lost to follow-up (five with ICM, twelve with DCM, two with myocarditis, and one with cardiac amyloidosis). The mean WCD wear 
time of patients with newly diagnosed HFrEF was $77 \pm 44$ for patients without a prolonged WCD prescription and $184 \pm 93$ days for patients with a prolonged WCD prescription. Mean daily wear time was $22 \pm 4 \mathrm{~h}$. There were no significant differences in WCD wear time between HFrEF groups.

In patients with an explanted ICD, the mean follow-up period was $3.2 \pm 1.8$ years and one patient was lost to follow-up (3\%). Patients with an explanted ICD had a mean WCD wear time of $55 \pm 45$ days and a daily wear time of $22 \pm 1 \mathrm{~h}$.

\subsection{Medication}

In patients with newly diagnosed HFrEF, medical heart failure therapy was initiated at the time of first diagnosis and optimized during hospital stay and further follow-ups. Beta-blockers were initiated in $94 \%$, angiotensin-converting enzyme inhibitors (ACEI) or angiotensin II receptor blockers (ARB) in $96 \%$ and mineralocorticoid receptor antagonists (MRA) in $88 \%$ of patients. Diuretics were prescribed in $81 \%$, ivabradine in $22 \%$, and digitalis in $9 \%$ of patients. From the initialization of medical therapy until three months follow-up, drug dosages of beta-blocker, ACEI/ARB and/or MRA were increased in $61 \%$ of patients (beta-blocker in 36\%, ACEI/ARB in 42\%, and MRA in 22\%). Between three months follow-up and last follow-up, another increase in dosages was noted in $45 \%$ of patients (beta-blocker in 26\%, ACEI/ARB in 24\%, and MRA in 17\%). Medication was not significantly increased during the follow-up period in the patient cohort receiving the WCD after ICD explantation.

\subsection{LVEF Recovery}

In patients with newly diagnosed HFrEF, LVEF showed significant improvement within the first three months in all ICM, DCM, PPCM, and myocarditis ( $p<0.001$ each). The degree of LVEF improvement differed. Within the first three months, patients with DCM improved significantly more than patients with $\operatorname{ICM}(9 \pm 9 \%$ vs $5 \pm 8 \%, p<0.002)$. Patients with PPCM improved $20 \pm 10 \%$, significantly more compared to both ICM and $\operatorname{DCM}(p<0.001$ each). Patients with myocarditis improved $15 \pm 9 \%(p<0.001$ compared to ICM and 0.08 compared to DCM). After three months, LVEF continued to improve significantly until last follow-up in patients with both PPCM $(10 \pm 8 \% ; p<0.024)$ and DCM $(10 \pm 12 \% ; p<0.001)$, but not significantly in patients with ICM, myocarditis, or other diagnoses. Data on LVEF recovery are summarized in Figure 1. NYHA functional class also improved in all subgroups within the first three months $(p<0.001$ each), but beyond three months NYHA functional class improved in PPCM $(p=0.03)$ and DCM $(p=0.02)$ only. In the patient cohort with an explanted ICD, neither LVEF nor NYHA class changed significantly during follow-up. 


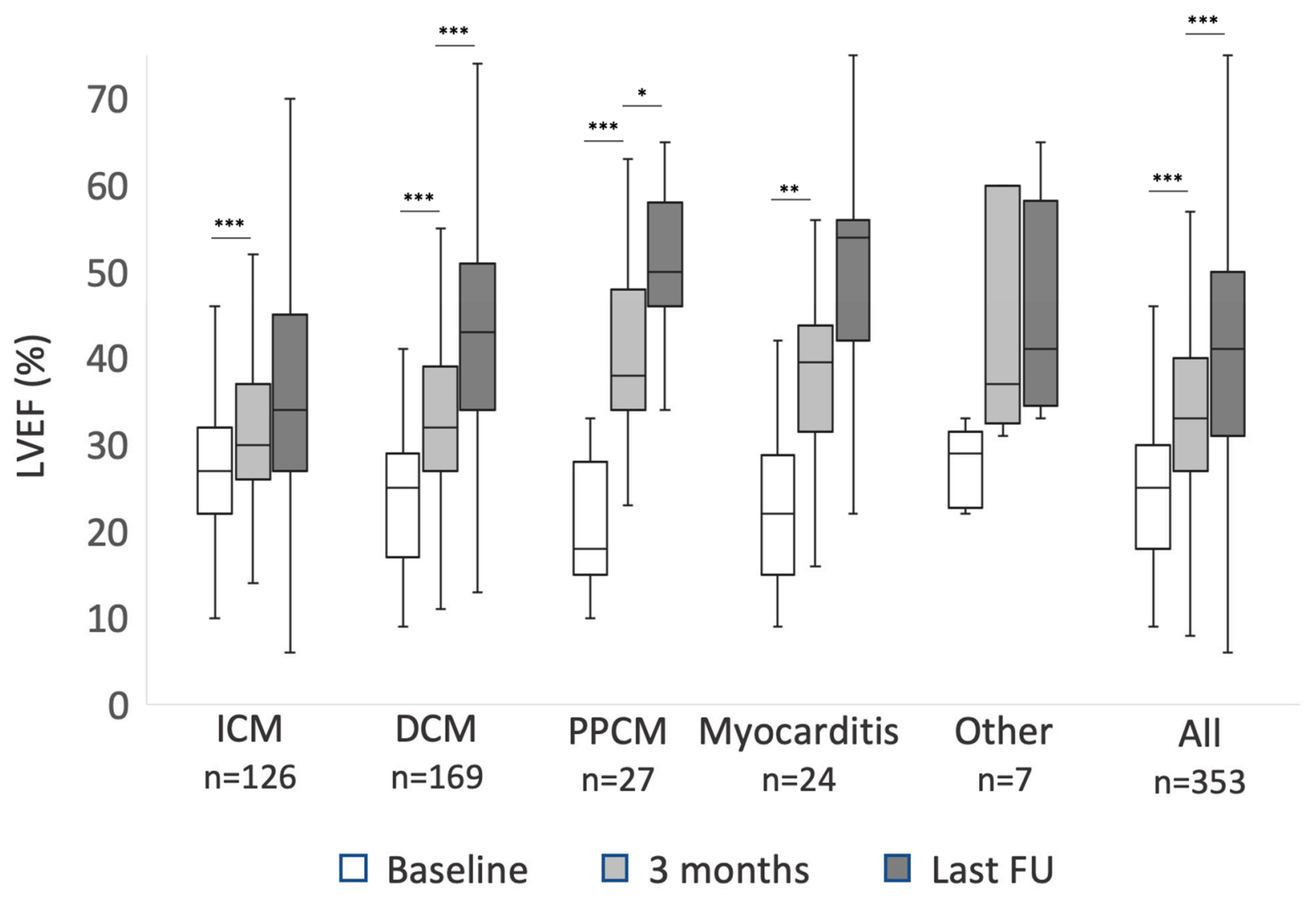

Figure 1. The improvement of left ventricular ejection fraction (LVEF) during follow-up of patients with newly diagnosed heart failure with reduced ejection fraction (HFrEF): mean values at baseline, three months, and last available follow-up (FU) for patients with ischemic cardiomyopathy (ICM), dilated cardiomyopathy (DCM), peripartum cardiomyopathy (PPCM), myocarditis and other diagnosis. Asterisks mark $p$-values $<0.05\left(^{*}\right),<0.01\left(^{* *}\right)$ and $<0.001\left(^{* * *}\right)$. Difference between 3 months and last FU LVEF in patients with myocarditis did not meet statistical significance with $p=0.09$.

\subsection{ICD Implantations}

Patients with newly diagnosed HFrEF who experienced appropriate WCD shocks while wearing WCD received an ICD for secondary prevention. A primary preventive ICD was implanted after three months only in cases where no further LVEF recovery was anticipated, based on previously described criteria [13]. These ICD implantation criteria were met in 63 patients with ICM (50\%), 46 patients with DCM $(27 \%), 2$ patients with PPCM (7\%), 1 with myocarditis (4\%), and one with congenital heart disease. Eighty-eight patients (25\%) still had an LVEF $\leq 35 \%$ at three months, but further LVEF improvement was anticipated. The risk stratification period under protection of the WCD was prolonged in this group of patients. Twenty-one of them had ICM (17\%), 45 had DCM (27\%), 12 had $\operatorname{PPCM}(44 \%), 8$ had myocarditis (33\%), and 2 had other diagnoses (one with cardiac involvement of eosinophilic granulomatosis with polyangiitis and one with cardiac transplant vasculopathy). Of these patients with prolonged WCD wearing, $31(35 \%)$ received an ICD after the extended WCD period: 11 with ICM (52\%), 15 with DCM (33\%), 3 with PPCM $(25 \%)$ and 2 with myocarditis (25\%). These data are illustrated in Figure 2. 


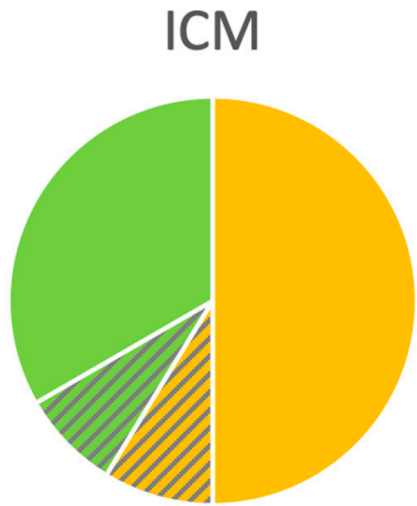

PPCM

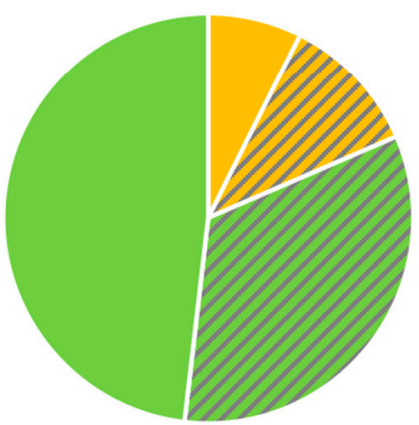

DCM

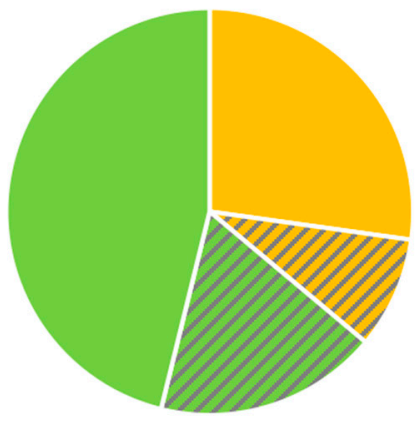

Myocarditis

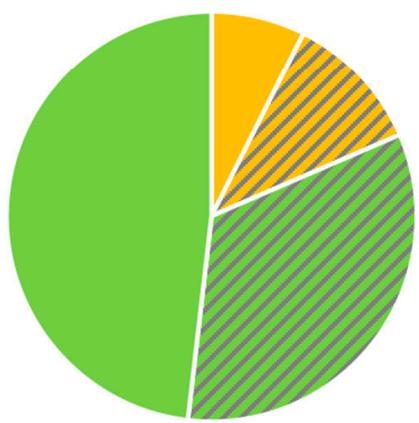

No ICD implantation

ICD implantation

After extended risk stratification

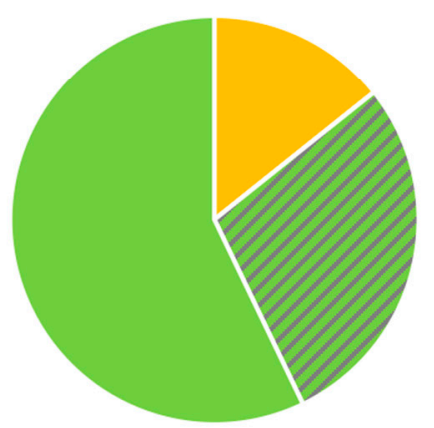

Figure 2. Implantable cardioverter-defibrillator (ICD) implantations during follow-up (FU). For each etiology of heart failure with reduced ejection fraction (HFrEF), proportion of patients meeting ICD implantation criteria or not after the wearable cardioverter-defibrillator (WCD) are depicted. Pie charts also show the proportion of patients with an extended period of therapy optimization before decision-making. $\mathrm{n}=353$ : 126 ICM (ischemic cardiomyopathy), 169 DCM (dilated cardiomyopathy), 27 PPCM (peripartum cardiomyopathy), 24 myocarditis, and seven other NICM.

\subsection{Ventricular Arrhythmias}

To assess the risk of early and late sudden cardiac death in newly diagnosed HFrEF, the occurrence of life-threatening ventricular arrhythmias (fast ventricular tachycardia $>200$ beats per minute or ventricular fibrillation) treated by the WCD or a later implanted ICD was assessed. Patients without an ICD recommendation after the WCD did not experience clinically relevant ventricular arrhythmias or sudden cardiac death during follow-up.

Patients with PPCM were most likely to experience early life-threatening arrhythmias treated by the WCD (11\%), but had no further arrhythmias during long-term follow-up. Patients with ICM and DCM received early WCD shocks in 4\% each, and later ICD therapies in $6 \%$ and $2 \%$, respectively $(16 \%$ and $11 \%$ of the patients receiving an ICD, respectively; the difference was non-significant). WCD shocks were predictive for appropriate ICD shocks in ICM $(p=0.01)$ and DCM $(p=0.02)$. Patients with myocarditis and other diagnoses had no ventricular arrhythmias.

Among the second, distinct patient group with an explanted ICD, WCD shocks occurred in three patients $(10 \%)$. During follow-up, a new ICD was implanted in 24 patients $(83 \%)$, and six of these patients (25\%) experienced ICD therapies during follow-up. Compared to the patient cohort with newly diagnosed HFrEF, ICD shocks occurred more often in this explant cohort $(p=0.015)$. 


\subsection{Mortality}

Death occurred in nine patients with ICM $(7 \%)$ after $1 \pm 1.1$ years (one sudden cardiac death in a patient who had refused primary preventive ICD implantation after the WCD, five non-cardiac deaths, three deaths with unknown cause). Death occurred in 20 patients with DCM (12\%) after $1.5 \pm 1.1$ years (4 non-sudden cardiac deaths, 11 non-cardiac deaths, 3 deaths with unknown cause). Death occurred in none of the patients with PPCM and in one patient with myocarditis ( $4 \%$ ), who died of relapse myocarditis and septic shock under immunosuppression after 1.1 years. Out of the deaths of unknown cause, none occurred in any of the patients with a prolonged WCD/risk stratification period. Differences in the Kaplan-Meier survival curves did not meet statistical significance. The latter are presented in Figure 3.

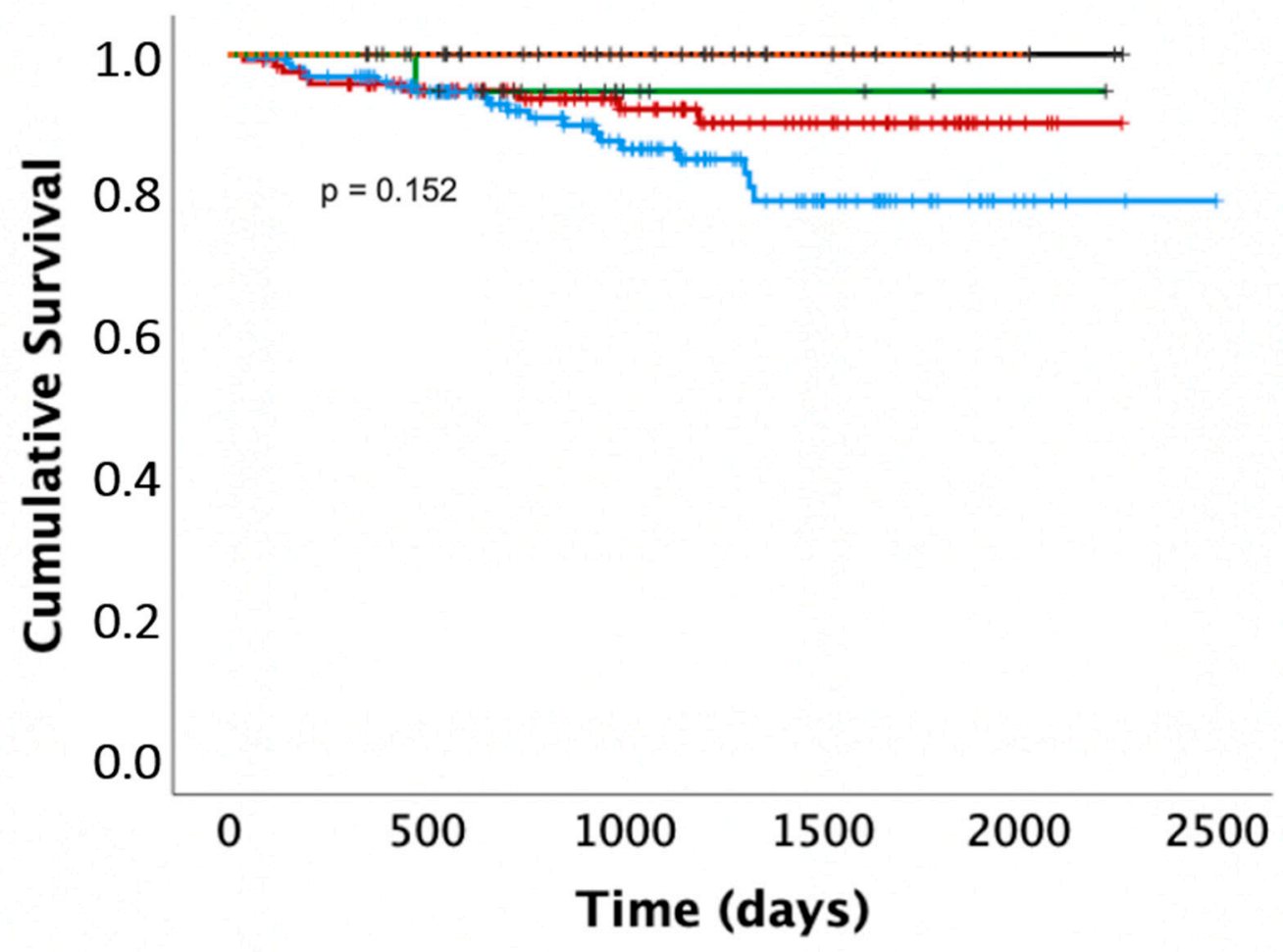

\section{$\triangle \mathrm{IICM}$ $\triangle P P C M$ $\triangle \mathrm{DCM}$ $\neg$ Myocarditis ": Other NICM}

Figure 3. Kaplan-Meier survival curves. ICM, ischemic cardiomyopathy; DCM, dilated cardiomyopathy; PPCM, peripartum cardiomyopathy; NICM, non-ischemic cardiomyopathy.

Patients with an explanted ICD showed significantly higher mortality compared to patients with newly diagnosed $\operatorname{HFrEF}(p=0.02)$. Seven $(24 \%)$ of the patients died after $0.9 \pm 1$ years (one of sudden cardiac death, one of non-sudden cardiac death, three of non-cardiac death, two with unknown cause of death). These included two out of three patients who had received appropriate WCD shocks during WCD wearing. Death occurred after 0.4 and 0.7 years (the association between WCD shocks and mortality in this patient group was significant; $p=0.045$ ). The Kaplan-Meier curves are presented in Figure 4. 


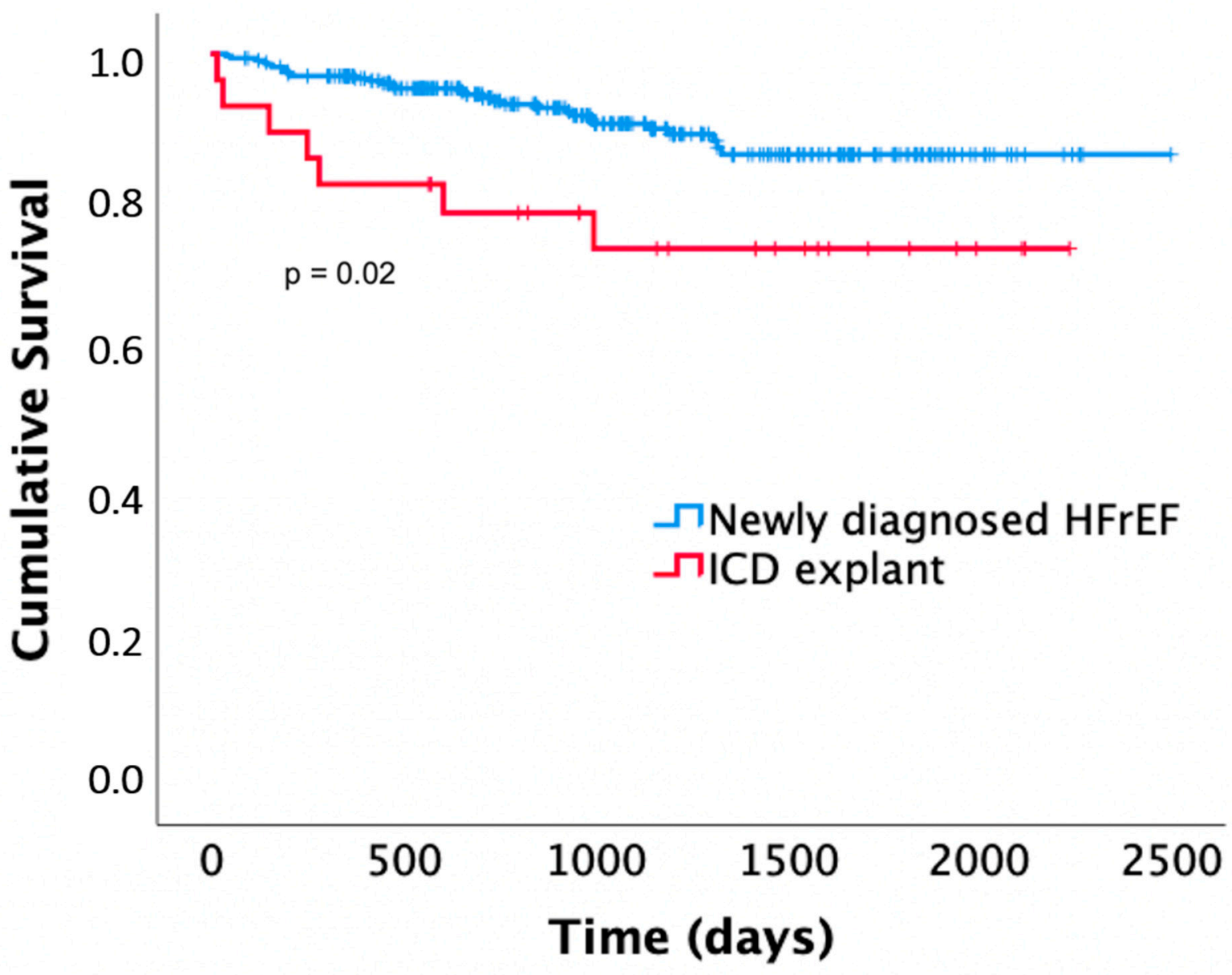

Figure 4. Kaplan-Meier survival curves of patients receiving the WCD for newly diagnosed heart failure with reduced ejection fraction (HFrEF) compared to patients receiving the WCD after ICD explantation.

\section{Discussion}

While the prognosis of patients with HFrEF is improving, ICD complication rates remain non-negligible $[6,7,9,28]$. The net benefit of a primary preventive ICD has been questioned by recent trials, especially in patients with non-ischemic cardiomyopathy [29-32]. As a consequence, guideline recommendations by the ESC were downgraded for patients with non-ischemic cardiomyopathy [5]. We and others have previously argued that a prolonged time should be taken for therapy optimization and risk stratification before deciding on ICD implantation [13-15]. The PROLONG and PROLONG-II study have suggested that ICD implantations can be avoided in some patients with newly diagnosed HFrEF by this practice without increasing the risk of sudden cardiac death $[13,23]$. The present analysis was conducted to evaluate which patients benefit from an extended waiting period. The main findings were:

1. In patients with newly diagnosed HFrEF, LVEF improved significantly beyond the first three months of optimized heart failure therapy in patients with DCM and PPCM;

2. Following the PROLONG protocol, a minority of these patients met criteria for ICD implantation;

3. Patients receiving the WCD because of prior ICD explantation showed a higher all-cause mortality compared to patients with newly diagnosed HFrEF.

\subsection{Baseline Characteristics}

Baseline characteristics of patients with HFrEF were similar compared to other heart failure studies [29,31,33-35]. As expected, there were age and gender differences between HFrEF entities and also differences in terms of comorbidities, which play an important 
role in the prognosis of heart failure patients [36-41]. As expected, patients with PPCM were younger and had few comorbidities [42,43]. As was also observed in other studies, patients with DCM were younger than patients with ICM, had fewer comorbidities, and a lower baseline LVEF [44,45]. Patients with DCM in our cohort more often had renal disease, indicating a sicker patient population. Patients with myocarditis were also sicker and older compared to most myocarditis trials [46-50]. However, these trials included patients with mildly reduced and preserved LVEF, while patients with myocarditis included in the present study had exclusively reduced ejection fraction.

The present study also analyzed a second, distinct patient cohort receiving the WCD after ICD explantation due to infection. These patients were older compared to patients with newly diagnosed HFrEF. Patients with ICD explantation typically have long-standing chronic heart failure and optimized medical therapy is established. Therefore, not surprisingly, these patients had lower NT-proBNP levels, lower NYHA class, higher LVEF values, and several comorbidities. Ischemic cardiomyopathy was the most common underlying heart disease, around half of the patients had a secondary preventive ICD indication, and they were predominantly male. Similar characteristics have also been described by others [51-55].

\subsection{LVEF Recovery under Optimized Therapy}

The guideline-directed medical therapy that was initiated after the diagnosis of HFrEF was more guideline-accordant than in most other heart failure studies and real-world data, with beta-blockers prescribed in 94\%, ACEI/ARB in $96 \%$, and MRA in $88 \%$ of patients $[29,56-58]$. This is likely related to the fact that the study was conducted at a single specialized heart failure center. Heart failure medication was further increased in $60 \%$ of patients within the first three months following diagnosis, and in $45 \%$ beyond that time. WCD compliance was excellent in the PROLONG-II study. To improve patient adherence, patients were contacted when WCD wear-time alerts occurred [23]. Compliance is crucial for effectiveness of the WCD. In contrast to the present study, WCD compliance was poor in the randomized controlled VEST trial, which failed to show a survival benefit of the WCD in the intention-to-treat analysis [20,59]. These data illustrate the advantages of referring heart failure patients to a heart failure center or heart failure specialist. The importance of close patient follow-up and education was also demonstrated by others [60-62]. Moreover, three months may not be enough time to establish individual optimized medication in many patients. Of note, the present study was initiated in 2012, and therefore before the approval and recommendation of angiotensin receptor-neprilysin inhibitors (ARNI) and SGLT-2 inhibitors. According to current guidelines, all beta-blockers, ACEI/ARB or ARNI, MRA and SGLT-2 should be initiated after diagnosis [5]. As HFrEF therapy becomes more complex, the establishment of stable optimized therapy may take even more time [14,58].

As expected after our previous data analysis, LVEF improved significantly under treatment [13]. The present study shows significant differences in LVEF recovery among HFrEF entities. Patients with PPCM and myocarditis showed the most marked LVEF recovery, and patients with ICM the least. Patients with PPCM and DCM showed another improvement in LVEF beyond the first three months, while patients with ICM and myocarditis did not. This finding is in line with the overall expected good prognosis of patients with PPCM, but importantly, a similar further LVEF improvement of around 10\% was observed in DCM patients. Patients with ICM may have reduced potential for reverse remodeling due to scar formation [63-65]. In myocarditis, further improvement may have been expected [66], and was seen as a trend in the present study. Mean LVEF values suggested a relevant improvement beyond three months, but statistical significance was missed, most likely due to the small sample size. Moreover, patients with myocarditis represent a very heterogenous group with heterogenous response to treatment [67-69].

In patients with an explanted ICD, neither a relevant escalation of heart failure therapy nor improvement of LVEF was noted, confirming the fact that these patients had chronic heart failure under already stable medical therapy. In contrast to patients with newly 
diagnosed heart failure, patients with chronic heart failure have lower overall potential for clinical improvement [70-74].

\subsection{Ventricular Arrhythmias and Implications for ICD Timing}

To elucidate the benefit of a WCD and/or ICD, the incidences of early and late lifethreatening ventricular arrhythmias were studied. It has been shown previously that patients with both ICM and NICM experience life-threatening arrhythmias following diagnosis [1-4]. In the present study, patients with PPCM experienced early, but no late arrhythmias: $11 \%$ received WCD shocks, but no later ICD shocks occurred. This is in accordance with the good long-term prognosis of patients with PPCM despite the early risk of arrhythmias, supporting the use of the WCD and questioning ICD primary preventive therapy in this particular patient group $[42,75,76]$. The young age of this patient group must also be considered in terms of risk for long-term complications associated with ICD therapy $[77,78]$. In patients with ICM and DCM, on the other hand, both early and late ventricular arrhythmias occurred, and WCD shocks were predictive for ICD shocks. Patients without an ICD recommendation after the PROLONG protocol did not suffer from ventricular arrhythmias or sudden cardiac death during extended follow-up, which was an important confirmatory finding concerning the safety of the prolonged risk stratification with less ICD implantations [13,23].

Patients with an explanted ICD experienced WCD shocks in $10 \%$ of cases and were also likely to receive ICD therapies after re-implantation ( $25 \%$ of patients). These data confirm the high arrhythmic risk in these patients $[24,25,27,79]$.

\subsection{Overall Mortality}

We have previously shown that the overall prognosis of patients with newly diagnosed HFrEF wearing the WCD during thorough therapy optimization is favorable compared to historical cohorts, and that ICD implantations can be avoided without signs of an increased risk of sudden cardiac death $[13,23]$. Analysis of the different HFrEF entities in the present study shows that prognosis is especially favorable in patients with PPCM. Only four patients received an ICD $(15 \%)$. None of the patients died after a mean follow-up of $3.2 \pm 1.5$ years. Differences in overall mortality between the other diagnoses were not statistically significant, although Kaplan-Meier curves suggested a worse survival in DCM patients. Other studies have suggested that DCM patients have an overall slightly better survival compared to ICM patients [80]. However, DCM patients in the present study often had renal disease, which is an important prognostic marker and may partly explain the poorer survival of DCM patients in our study [44].

Patients with a previously explanted ICD showed poorer survival compared to patients with newly diagnosed heart failure. Besides suffering from chronic heart failure and comorbidities, ICD infection and explantation procedure also confer a high mortality risk $[81,82]$.

\subsection{Implications for ICD Timing and WCD Prescription}

Optimal timing of ICD evaluation may be challenging in patients with $\mathrm{HFrEF}$, as patients have a risk of sudden cardiac death, but their long-term risk is unknown at the time of diagnosis $[14,15]$. Most studies investigating ICD therapy were conducted before the era of modern pharmacological heart failure therapy [83-87]. Since then, the prognosis of heart failure patients has improved [11,40]. Because of relevant complication rates, unnecessary ICD implantations should be avoided and ICD indications evaluated critically $[9,88]$. In fact, ICD implantation numbers have recently declined $[89,90]$. The present study suggests that patients with DCM and especially PPCM have the potential for continuing LVEF recovery under continued optimized treatment, resulting in less ICD indications. Patients with ICM, on the other hand, showed less reverse remodeling, which is in concordance with previous observations [63,65]. Most patients with ICM did receive an ICD despite prolonged risk stratification, and the patients did not show significant 
recovery beyond the first three months. Therefore, HFrEF entity should be considered when evaluating ICD indication.

We performed the extended risk stratification under temporary protection of the WCD. The present study shows a relevant incidence of WCD shocks, supporting the use of the WCD during risk stratification in newly diagnosed HFrEF. According to our and other data, patients with PPCM are particularly suited for prolonged WCD therapy and WCD therapy in general, as they show relevant early ventricular arrhythmias but have an overall good prognosis, and rarely seem to need long-term ICD therapy $[75,91]$. These observations might also be valid for young patients with non-ischemic cardiomyopathy without comorbidities in general. Concerning the costs of a prolonged WCD therapy, these should also be weighed against the costs of life-long ICD therapy [92-94].

Another WCD indication is the explantation of a previously implanted ICD, which seems to be less controversially discussed in comparison to the indication in newly diagnosed HFrEF [24,53,95-97]. However, there is a lack of evidence of a survival benefit of the WCD in this patient group, and a paucity of data on prognosis and arrhythmia burden. Our study results show a relevant number of arrhythmias in this patient group. However, overall mortality is also high. It remains unclear whether the WCD conveys a long-term survival benefit in this population [27].

\section{Conclusions}

In newly diagnosed HFrEF, underlying heart disease should be considered when deciding on the timing of ICD implantation. An extended risk stratification under optimized treatment and the temporary protection of the WCD may be considered, particularly in patients with DCM, PPCM, and possibly myocarditis, who show marked LVEF recovery beyond the first three months after diagnosis.

\section{Limitations}

PROLONG-II was a retrospective observational study conducted at a specialized heart failure center experienced with WCD therapy. Thus, patient adherence to therapy was high. To improve compliance and optimization of therapy, patients were contacted frequently. While this may limit generalizability, it was the aim of the study to show LVEF recovery under optimized, guideline-directed heart failure therapy. Notably, treatment with newer heart failure drugs was not assessed in the study. The group of patients with myocarditis was small and heterogenous, with no ventricular arrhythmias during follow-up. Therefore, limited conclusions can be drawn for this specific entity.

Author Contributions: Conceptualization, D.D., J.M.-L. and C.V.; methodology, D.D., J.M.-L. and C.V.; validation, D.D., J.M.-L., C.V., J.B. (Johanna Brunn), C.Z., S.H., H.A.K.H., J.E. and J.B. (Johann Bauersachs); formal analysis, D.D., J.M.-L., C.V. and J.B. (Johanna Brunn); investigation, D.D., J.M.-L. and J.B. (Johanna Brunn); data curation, D.D., J.M.-L. and J.B. (Johanna Brunn); writing-original draft preparation, J.M.-L.; writing—review and editing for substantial scientific content, D.D., J.B. (Johanna Brunn), C.V., C.Z., S.H., H.A.K.H., J.E. and J.B. (Johann Bauersachs); visualization, J.M.-L., D.D. and C.V.; supervision, D.D. and C.V.; project administration, D.D., J.M.-L., C.V., J.B. (Johanna Brunn), C.Z., S.H., H.A.K.H., J.E. and J.B. (Johann Bauersachs). All authors have read and agreed to the published version of the manuscript.

Funding: This research received no external funding.

Institutional Review Board Statement: The study was conducted according to the guidelines of the Declaration of Helsinki, and approved by the local ethics committee of Hannover Medical School (protocol code 7615; 4 October 2017).

Informed Consent Statement: Informed consent was obtained from all subjects involved in the study.

Data Availability Statement: Raw data were generated at Hannover Medical School. Derived data are available from the corresponding author upon reasonable request. 
Conflicts of Interest: D.D. received lecture honorary, travel grants and/or a fellowship grant from Abbott, Astra Zeneca, Biotronik, Boehringer Ingelheim, Boston Scientific, Bristol Myers Squibb, Medtronic, Microport, Pfizer, Zoll. C.V. received lecture honorary for lectures and/or consulting from Abbott, Astra Zeneca, Bayer, Biotronik, BMS, Boehringer Ingelheim, Boston Scientific, CVRx, Medtronic, Pfizer, Zoll. J.B. (Johann Bauersachs) received honoraria for lectures and/or consulting from Novartis, BMS, Pfizer, Vifor, Bayer, Servier, Daichii Sankyo, CVRx, MSD, Boehringer Ingelheim, AstraZeneca, Abiomed, Abbott, Medtronic; and research support from Zoll, CVRx, Vifor, Abiomed. J.M.-L. received lecture honorary, travel grants and/or a fellowship grant from Medtronic, Boston Scientific and Biotronik. C.Z. received lecture honorary, travel grants and/or a fellowship grant from Biotronik and Medtronic. S.H. received a fellowship grant from Boston Scientific. H.A.K.H. and J.E. have no conflicts of interest to declare.

\section{References}

1. Mehta, P.A.; Dubrey, S.W.; McIntyre, H.F.; Walker, D.M.; Hardman, S.M.; Sutton, G.C.; McDonagh, T.A.; Cowie, M.R. Mode of death in patients with newly diagnosed heart failure in the general population. Eur. J. Heart Fail. 2008, 10, 1108-1116. [CrossRef]

2. Duncker, D.; König, T.; Hohmann, S.; Bauersachs, J.; Veltmann, C. Ventricular arrhythmias in patients with newly diagnosed nonischemic cardiomyopathy: Insights from the PROLONG study. Clin. Cardiol. 2017, 40, 586-590. [CrossRef] [PubMed]

3. Piccini, J.P.; Al-Khatib, S.M.; Myers, E.R.; Anstrom, K.J.; Buxton, A.E.; Peterson, E.D.; Sanders, G.D. Optimal Timing of Implantable Cardioverter-Defibrillator Implantation After Myocardial Infarction: A Decision Analysis. J. Cardiovasc. Electrophysiol. 2010, 21, 791-798. [CrossRef]

4. Makati, K.J.; Fish, A.E.; England, H.H.; Tighiouart, H.; Estes, N.M.; Link, M.S. Equivalent arrhythmic risk in patients recently diagnosed with dilated cardiomyopathy compared with patients diagnosed for 9 months or more. Heart Rhythm 2006, 3, 397-403. [CrossRef] [PubMed]

5. McDonagh, T.A.; Metra, M.; Adamo, M.; Gardner, R.S.; Baumbach, A.; Böhm, M.; Burri, H.; Butler, J.; Čelutkienė, J.; Chioncel, O.; et al. 2021 ESC Guidelines for the diagnosis and treatment of acute and chronic heart failure. Eur. Heart J. 2021, 42, 3599-3726. [CrossRef] [PubMed]

6. Taylor, C.J.; Ordóñez-Mena, J.M.; Roalfe, A.K.; Lay-Flurrie, S.; Jones, N.; Marshall, T.; Hobbs, F.D.R. Trends in survival after a diagnosis of heart failure in the United Kingdom 2000-2017: Population based cohort study. BMJ 2019, 364, 1223. [CrossRef] [PubMed]

7. Moliner, P.; Lupón, J.; de Antonio, M.; Domingo, M.; Santiago-Vacas, E.; Zamora, E.; Cediel, G.; Santesmases, J.; Díez-Quevedo, C.; Troya, M.I.; et al. Trends in modes of death in heart failure over the last two decades: Less sudden death but cancer deaths on the rise. Eur. J. Heart Fail. 2019, 21, 1259-1266. [CrossRef]

8. Shen, L.; Jhund, P.S.; Petrie, M.C.; Claggett, B.L.; Barlera, S.; Cleland, J.G.; Dargie, H.J.; Granger, C.B.; Kjekshus, J.; Køber, L.; et al. Declining Risk of Sudden Death in Heart Failure. N. Engl. J. Med. 2017, 377, 1794-1795. [CrossRef]

9. Hawkins, N.M.; Grubisic, M.; Andrade, J.G.; Huang, F.; Ding, L.; Gao, M.; Bashir, J. Long-term complications, reoperations and survival following cardioverter-defibrillator implant. Heart 2017, 104, 237-243. [CrossRef]

10. A Ezzat, V.; Lee, V.; Ahsan, S.; Chow, A.W.; Segal, O.; Rowland, E.; Lowe, M.D.; Lambiase, P.D. A systematic review of ICD complications in randomised controlled trials versus registries: Is our 'real-world' data an underestimation? Open Heart 2015, 2, e000198. [CrossRef]

11. Koneru, J.N.; Jones, P.W.; Hammill, E.F.; Wold, N.; Ellenbogen, K.A. Risk Factors and Temporal Trends of Complications Associated With Transvenous Implantable Cardiac Defibrillator Leads. J. Am. Heart Assoc. 2018, 7, e007691. [CrossRef]

12. Al-Khatib, S.M.; Hellkamp, A.S.; Curtis, J.P.; Mark, D.; Peterson, E.D.; Sanders, G.D.; Heidenreich, P.; Hernandez, A.F.; Curtis, L.H.; Hammill, S.C. Non-Evidence-Based ICD Implantations in the United States. JAMA 2011, 305, 43-49. [CrossRef] [PubMed]

13. Duncker, D.; König, T.; Hohmann, S.; Bauersachs, J.; Veltmann, C. Avoiding Untimely Implantable Cardiovert-er/Defibrillator Implantation by Intensified Heart Failure Therapy Optimization Supported by the Wearable Cardiovert-er/Defibrillator-The PROLONG Study. J. Am. Heart Assoc. 2017, 6, 69. [CrossRef] [PubMed]

14. DeFilippis, E.M.; Butler, J.; Vaduganathan, M. Waiting Period before Implantable Cardioverter-Defibrillator Im-plantation in Newly Diagnosed Heart Failure with Reduced Ejection Fraction: A Window of Opportunity. Circ. Heart Fail. 2017, 10, e004478. [CrossRef] [PubMed]

15. Wong, J.A.; Roberts, J.D.; Healey, J.S. The Optimal Timing of Primary Prevention Implantable Cardiovert-er-Defibrillator Referral in the Rapidly Changing Medical Landscape. Can. J.Cardiol. 2021, 37, 644-654. [CrossRef] [PubMed]

16. Goldberger, J.J.; Subačius, H.; Patel, T.; Cunnane, R.; Kadish, A.H. Sudden cardiac death risk stratification in patients with nonischemic dilated cardiomyopathy. J. Am. Coll. Cardiol. 2014, 63, 1879-1889. [CrossRef]

17. Duncker, D.; Veltmann, C. Role of the Wearable Defibrillator in Newly Diagnosed Heart Failure. Curr. Heart Fail. Rep. 2018, 15, 368-375. [CrossRef]

18. Duncker, D.; Veltmann, C. The Wearable Cardioverter/Defibrillator-Toy or Tool? J. Atr. Fibrillation 2016, 8. [CrossRef]

19. Duncker, D.; Veltmann, C. Wearable defibrillator: Current evidence. Herzschrittmacherther Elektrophysiol. 2018, 29, 362-368. [CrossRef] 
20. Olgin, J.E.; Pletcher, M.J.; Vittinghoff, E.; Wranicz, J.; Malik, R.; Morin, D.P.; Zweibel, S.; Buxton, A.E.; Elayi, C.S.; Chung, E.H.; et al. Wear-able Cardioverter-Defibrillator after Myocardial Infarction. N. Engl. J. Med. 2018, 379, 1205-1215. [CrossRef]

21. Bhatt, A.G.; Mittal, S. The wearable cardioverter-defibrillator is not needed for most high-risk patients. Heart Rhythm $\mathrm{O}_{2}$ 2020, 1 , 230-233. [CrossRef] [PubMed]

22. Jagadish, P.S.; Aziz, M.; Chinta, V.; Khouzam, R.N. Misunderstood or Mistrusted? The Under-Utilization of the Wearable Cardioverter Defibrillator in Clinical Practice. Curr. Probl. Cardiol. 2018, 45, 100395. [CrossRef] [PubMed]

23. Mueller-Leisse, J.; Brunn, J.; Zormpas, C.; Hohmann, S.; Hillmann, H.A.; Eiringhaus, J.; Bauersachs, J.; Veltmann, C.; Duncker, D. Extended follow-up after wearable cardioverter-defibrillator period: The PROLONG-II study. ESC Heart Fail. 2021, 8, 5142-5148. [CrossRef] [PubMed]

24. Ellenbogen, K.A.; Koneru, J.N.; Sharma, P.S.; Deshpande, S.; Wan, C.; Szymkiewicz, S.J. Benefit of the Wearable CardioverterDefibrillator in Protecting Patients after Implantable-Cardioverter Defibrillator Explant: Results from the Na-tional Registry. JACC Clin. Electrophysiol. 2017, 3, 243-250. [CrossRef] [PubMed]

25. Jiang, X.; Ming, W.; You, J.H.S. Potential cost-effectiveness of wearable cardioverter-defibrillator for patients with implantable cardioverter-defibrillator explant in a high-income city of China. J. Cardiovasc. Electrophysiol. 2019, 30, 2387-2396. [CrossRef]

26. Kaspar, G.; Sanam, K.; Gholkar, G.; Bianco, N.R.; Szymkiewicz, S.; Shah, D. Long-term use of the wearable car-dioverter defibrillator in patients with explanted ICD. Int. J. Cardiol. 2018, 272, 179-184. [CrossRef]

27. Chung, M.K. Mitigating Post-Extraction Risk: Is it Worth the inVESTment? JACC Clin. Electrophysiol. 2017, 3, 251-252. [CrossRef]

28. A Mehta, P.; Dubrey, S.W.; McIntyre, H.F.; Walker, D.; Hardman, S.M.C.; Sutton, G.C.; A McDonagh, T.; Cowie, M. Improving survival in the 6 months after diagnosis of heart failure in the past decade: Population-based data from the UK. Heart 2009, 95, 1851-1856. [CrossRef]

29. Køber, L.; Thune, J.J.; Nielsen, J.C.; Haarbo, J.; Videbæk, L.; Korup, E.; Jensen, G.; Hildebrandt, P.; Steffensen, F.H.; Bruun, N.E.; et al. DANISH Investigators, Defibrillator Implantation in Patients with Nonischemic Systolic Heart Failure. N. Engl. J. Med. 2016, 375, 1221-1230. [CrossRef]

30. Pathak, R.K.; Sanders, P.; Deo, R. Primary prevention implantable cardioverter-defibrillator and opportunities for sudden cardiac death risk assessment in non-ischaemic cardiomyopathy. Eur. Heart J. 2018, 39, 2859-2866. [CrossRef]

31. Saltzberg, M.T.; Szymkiewicz, S.; Bianco, N.R. Characteristics and outcomes of peripartum versus nonperipar-tum cardiomyopathy in women using a wearable cardiac defibrillator. J. Card. Fail. 2012, 18, 21-27. [CrossRef] [PubMed]

32. Khan, S.U.; Ghimire, S.; Talluri, S.; Rahman, H.; Khan, M.U.; Nasir, F.; Kaluski, E. Implantable cardioverter defib-rillator in nonischemic cardiomyopathy: A systematic review and meta-analysis. J. Arrhythmia 2018, 34, 4-10. [CrossRef] [PubMed]

33. GBrooks, G.C.; Lee, B.K.; Rao, R.; Lin, F.; Morin, D.P.; Zweibel, S.L.; Buxton, A.E.; Pletcher, M.J.; Vittinghoff, E.; Olgin, J.E. PREDICTS Investigators, Predicting Persistent Left Ventricular Dysfunction Following Myocardial Infarction: The PREDICTS Study. J. Am. Coll. Cardiol. 2016, 67, 1186-1196. [CrossRef] [PubMed]

34. Sjöblom, J.; Muhrbeck, J.; Witt, N.; Alam, M.; Frykman-Kull, V. Evolution of left ventricular ejection fraction after acute myocardial infarction: Implications for implantable cardioverter-defibrillator eligibility. Circulation 2014, 130, 743-748. [CrossRef]

35. Kubanek, M.; Sramko, M.; Maluskova, J.; Kautznerova, D.; Weichet, J.; Lupinek, P.; Vrbska, J.; Malek, I.; Kautzner, J. Novel Predictors of Left Ventricular Reverse Remodeling in Individuals With Recent-Onset Dilated Cardiomyopathy. J. Am. Coll. Cardiol. 2012, 61, 54-63. [CrossRef] [PubMed]

36. Jong, P.; Vowinckel, E.; Liu, P.; Gong, Y.; Tu, J. Prognosis and determinants of survival in patients newly hospitalized for heart failure. A Popul.-Based Study. ACC Curr. J. Rev. 2002, 11, 56. [CrossRef]

37. Cleland, J.G.; Carubelli, V.; Castiello, T.; Yassin, A.; Pellicori, P.; Antony, R. Renal dysfunction in acute and chronic heart failure: Prevalence, incidence and prognosis. Heart Fail. Rev. 2012, 17, 133-149. [CrossRef]

38. Lehrke, M.; Marx, N. Diabetes Mellitus and Heart Failure. Am. J. Cardiol. 2017, 120, S37-S47. [CrossRef]

39. Díez, J. Arterial Hypertension in Patients with Heart Failure. Heart Fail. Clin. 2014, 10, 233-242. [CrossRef] [PubMed]

40. Wittenbecher, C.; Eichelmann, F.; Toledo, E.; Guasch-Ferré, M.; Ruiz-Canela, M.; Li, J.; Arós, F.; Lee, C.H.; Liang, L.; Salas-Salvadó, J.; et al. Lipid Profiles and Heart Failure Risk: Results From Two Prospective Studies. Circ. Res. 2021, 128, 309-320. [CrossRef]

41. Mehta, P.A.; Cowie, M.R. Gender and heart failure: A population perspective. Heart 2006, 92, iii14-iii18. [CrossRef] [PubMed]

42. Bauersachs, J.; König, T.; van der Meer, P.; Petrie, M.C.; Hilfiker-Kleiner, D.; Mbakwem, A.; Hamdan, R.; Jackson, A.M.; Forsyth, P.; de Boer, R.A.; et al. Pathophysiology, diagnosis and management of peri-partum cardiomyopathy: A position statement from the Heart Failure Association of the European Society of Cardiology Study Group on peripartum cardiomyopathy. Eur. J. Heart Fail. 2019, 21, 827-843. [CrossRef] [PubMed]

43. Sliwa, K.; Fett, J.; Elkayam, U. Peripartum cardiomyopathy. Herz 2018, 43, 431-437.

44. Balmforth, C.; Simpson, J.; Shen, L.; Jhund, P.S.; Lefkowitz, M.; Rizkala, A.R.; Rouleau, J.L.; Shi, V.; Solomon, S.D.; Swedberg, K. Outcomes and Effect of Treatment According to Etiology in HFrEF: An Analysis of PARADIGM-HF. JACC Heart Fail. 2019, 7, 457-465. [CrossRef] [PubMed]

45. Hänselmann, A.; Veltmann, C.; Bauersachs, J.; Berliner, D. Dilated cardiomyopathies and non-compaction car-diomyopathy. Herz 2020, 45, 212-220. [CrossRef]

46. Kindermann, I.; Kindermann, M.; Kandolf, R.; Klingel, K.; Bültmann, B.; Müller, T.; Lindinger, A.; Böhm, M. Predictors of outcome in patients with suspected myocarditis. Circulation 2008, 118, 639-648. [CrossRef] 
47. Georgiopoulos, G.; Figliozzi, S.; Sanguineti, F.; Aquaro, G.D.; di Bella, G.; Stamatelopoulos, K.; Chiribiri, A.; Garot, J.; Masci, P.G.; Ismail, T.F. Prognostic Impact of Late Gadolinium Enhancement by Cardiovascular Magnetic Resonance in Myocarditis: A Systematic Review and Meta-Analysis. Circ. Cardiovasc. Imaging 2021, 14, e011492. [CrossRef]

48. Grün, S.; Schumm, J.; Greulich, S.; Wagner, A.; Schneider, S.; Bruder, O.; Kispert, E.-M.; Hill, S.; Ong, P.; Klingel, K.; et al. Long-Term Follow-Up of Biopsy-Proven Viral Myocarditis: Predictors of Mortality and Incomplete Recovery. J. Am. Coll. Cardiol. 2012, 59, 1604-1615. [CrossRef]

49. Tscholl, V.; Wielander, D.; Kelch, F.; Stroux, A.; Attanasio, P.; Tschöpe, C.; Landmesser, U.; Roser, M.; Huemer, M.; Heidecker, B.; et al. Benefit of a wearable cardioverter defibrillator for detection and therapy of arrhythmias in pa-tients with myocarditis. ESC Heart Fail. 2021, 8, 2428-2437. [CrossRef]

50. Gräni, C.; Eichhorn, C.; Bière, L.; Murthy, V.L.; Agarwal, V.; Kaneko, K.; Cuddy, S.; Aghayev, A.; Steigner, M.; Blankstein, R.; et al. Prognostic Value of Cardiac Magnetic Resonance Tissue Characterization in Risk Stratifying Patients With Suspected Myocarditis J. Am. Coll. Cardiol. 2017, 70, 1964-1976. [CrossRef]

51. Greenspon, A.J.; Le, K.Y.; Prutkin, J.M.; Sohail, M.R.; Vikram, H.R.; Baddour, L.M.; Danik, S.B.; Peacock, J.; Falces, C.; Miro, J.M.; et al. Influence of vegetation size on the clinical presentation and outcome of lead-associated endocarditis: Results from the MEDIC registry. JACC Cardiovasc. Imaging 2014, 7, 541-549. [CrossRef] [PubMed]

52. Tarakji, K.G.; Wazni, O.M.; Harb, S.; Hsu, A.; Saliba, W.; Wilkoff, B.L. Risk factors for 1-year mortality among patients with cardiac implantable electronic device infection undergoing transvenous lead extraction: The impact of the infec-tion type and the presence of vegetation on survival. Europace 2014, 16, 1490-1495. [CrossRef] [PubMed]

53. Castro, L.; Pecha, S.; Linder, M.; Vogler, J.; Gosau, N.; Meyer, C.; Willems, S.; Reichenspurner, H.; Hakmi, S. The wearable cardioverter defibrillator as a bridge to reimplantation in patients with ICD or CRT-D-related infections. J. Cardiothorac. Surg. 2017, 12, 99. [CrossRef] [PubMed]

54. Pichlmaier, M.; Knigina, L.; Kutschka, I.; Bara, C.; Oswald, H.; Klein, G.; Bisdas, T.; Haverich, A. Complete removal as a routine treatment for any cardiovascular implantable electronic device-associated infection. J. Thorac. Cardiovasc. Surg. 2011, 142, 1482-1490. [CrossRef]

55. Grammes, J.A.; Schulze, C.M.; Al-Bataineh, M.; Yesenosky, G.A.; Saari, C.S.; Vrabel, M.J.; Horrow, J.; Chowdhury, M.; Fontaine, J.M.; Kutalek, S.P. Percutaneous Pacemaker and Implantable Cardioverter-Defibrillator Lead Extraction in 100 Patients With Intracardiac Vegetations Defined by Transesophageal Echocardiogram. J. Am. Coll. Cardiol. 2010, 55, 886-894. [CrossRef]

56. McMurray, J.J.; Packer, M.; Desai, A.S.; Gong, J.; Lefkowitz, M.P.; Rizkala, A.R.; Rouleau, J.L.; Shi, V.C.; Solomon, S.D.; Swedberg, K.; et al. Angiotensin-neprilysin inhibition versus en-alapril in heart failure. N. Engl. J. Med. 2014, 371, 993-1004. [CrossRef]

57. Singh, J.P.; Klein, H.U.; Huang, D.T.; Reek, S.; Kuniss, M.; Quesada, A.; Barsheshet, A.; Cannom, D.; Goldenberg, I.; McNitt, S.; et al. Left ventricular lead position and clinical outcome in the multicenter au-tomatic defibrillator implantation trial-cardiac resynchronization therapy (MADIT-CRT) trial. Circulation 2011, 123, 1159-1166. [CrossRef]

58. Wirtz, H.S.; Sheer, R.; Honarpour, N.; Casebeer, A.W.; Simmons, J.D.; Kurtz, C.E.; Pasquale, M.K.; Globe, G. Real-World Analysis of Guideline-Based Therapy After Hospitalization for Heart Failure. J. Am. Heart Assoc. 2020, 9, e015042. [CrossRef]

59. Olgin, J.E.; Lee, B.K.; Vittinghoff, E.; Morin, D.P.; Zweibel, S.; Rashba, E.; Chung, E.H.; Borggrefe, M.; Hulley, S.; Lin, F.; et al Impact of wearable cardioverter-defibrillator compliance on outcomes in the VEST trial: As-treated and per-protocol analyses. J. Cardiovasc. Electrophysiol. 2020, 31, 1009-1018. [CrossRef]

60. Lyratzopoulos, G.; A Cook, G.; McElduff, P.; Havely, D.; Edwards, R.; Heller, R.F. Assessing the impact of heart failure specialist services on patient populations. BMC Health Serv. Res. 2004, 4, 10. [CrossRef]

61. Thomas, R.L.; Huntley, A.; Mann, M.; Huws, D.; Paranjothy, S.; Elwyn, G.; Purdy, S. Specialist clinics for reducing emergency admissions in patients with heart failure: A systematic review and meta-analysis of randomised controlled trials. Heart 2013, 99, 233-239. [CrossRef] [PubMed]

62. Koelling, T.M.; Johnson, M.L.; Cody, R.J.; Aaronson, K.D. Discharge Education Improves Clinical Outcomes in Patients With Chronic Heart Failure. Circulation 2005, 111, 179-185. [CrossRef] [PubMed]

63. Lee, Y.H.; Chiou, W.R.; Hsu, C.Y.; Lin, P.L.; Liang, H.W.; Chung, F.P.; Liao, C.T.; Lin, W.Y.; Chang, H.Y. Different left ventricular remodeling patterns and clinical outcomes between non-ischemic and ischemic etiologies in heart failure patients receiving sacubitril/valsartan treatment. Eur. Heart J. Cardiovasc. Pharm. 2020, 8, 118-129. [CrossRef] [PubMed]

64. Zhang, Y.; Guallar, E.; Weiss, R.G.; Stillabower, M.; Gerstenblith, G.; Tomaselli, G.F.; Wu, K.C. Associations be-tween scar characteristics by cardiac magnetic resonance and changes in left ventricular ejection fraction in primary preven-tion defibrillator recipients. Heart Rhythm 2016, 13, 1661-1666. [CrossRef]

65. Kloosterman, M.; van Stipdonk, A.M.; Ter Horst, I.; Rienstra, M.; Van Gelder, I.C.; Vos, M.A.; Prinzen, F.W.; Meine, M.; Vernooy, K.; Maass, A.H. Association between heart failure aetiology and magnitude of echocardiographic re-modelling and outcome of cardiac resynchronization therapy. ESC Heart Fail. 2020, 7, 645-653. [CrossRef]

66. Ammirati, E.; Cipriani, M.; Lilliu, M.; Sormani, P.; Varrenti, M.; Raineri, C.; Petrella, D.; Garascia, A.; Pedrotti, P.; Roghi, A.; et al. Survival and Left Ventricular Function Changes in Fulminant Versus Nonfulminant Acute Myocarditis. Circulation 2017, 136, 529-545. [CrossRef]

67. Tschöpe, C.; Cooper, L.T.; Torre-Amione, G.; Van Linthout, S. Management of Myocarditis-Related Cardiomyo-pathy in Adults. Circ. Res. 2019, 124, 1568-1583. [CrossRef] 
68. Tschöpe, C.; Ammirati, E.; Bozkurt, B.; Caforio, A.L.P.; Cooper, L.T.; Felix, S.B.; Hare, J.M.; Heidecker, B.; Heymans, S.; Hübner, N.; et al. Myocarditis and inflammatory cardiomyopathy: Current evidence and future directions. Nat. Rev. Cardiol. 2020, 18, 169-193. [CrossRef]

69. Li, H.S.; Ligons, D.L.; Rose, N.R. Genetic complexity of autoimmune myocarditis. Autoimmun. Rev. 2008, 7, 168-173. [CrossRef]

70. Gheorghiade, M.; Greene, S.J.; Butler, J.; Filippatos, G.; Lam, C.S.P.; Maggioni, A.P.; Ponikowski, P.; Shah, S.J.; Solomon, S.D.; Kraigher-Krainer, E.; et al. Effect of Vericiguat, a Soluble Guanylate Cyclase Stimulator, on Natriuretic Peptide Levels in Patients With Worsening Chronic Heart Failure and Reduced Ejection Fraction: The SOCRATES-REDUCED Randomized Trial. JAMA 2015, 314, 2251-2262. [CrossRef]

71. Metra, M.; Ponikowski, P.; Dickstein, K.; McMurray, J.J.; Gavazzi, A.; Bergh, C.-H.; Fraser, A.G.; Jaarsma, T.; Pitsis, A.; Mohacsi, P.; et al. Advanced chronic heart failure: A position statement from the Study Group on Advanced Heart Failure of the Heart Failure Association of the European Society of Cardiology. Eur. J. Heart Fail. 2007, 9, 684-694. [CrossRef] [PubMed]

72. Cicoira, M.; Rossi, A.; Chiampan, A.; Frigo, G.; Bergamini, C.; Rigolli, M.; Zanolla, L.; Vassanelli, C. Identification of High-Risk Chronic Heart Failure Patients in Clinical Practice: Role of Changes in Left Ventricular Function. Clin. Cardiol. 2012, 35, 580-584. [CrossRef] [PubMed]

73. Greene, S.J.; Hernandez, A.F.; Dunning, A.; Ambrosy, A.P.; Armstrong, P.W.; Butler, J.; Cerbin, L.P.; Coles, A.; Ezekowitz, J.A.; Metra, M.; et al. Hospitalization for Re-cently Diagnosed Versus Worsening Chronic Heart Failure: From the ASCEND-HF Trial. J. Am. Coll. Cardiol. 2017, 69, 3029-3039. [CrossRef] [PubMed]

74. Younis, A.; Mulla, W.; Goldkorn, R.; Klempfner, R.; Peled, Y.; Arad, M.; Freimark, D.; Goldenberg, I. Differences in Mortality of New-Onset (De-Novo) Acute Heart Failure Versus Acute Decompensated Chronic Heart Failure. Am. J. Cardiol. 2019, 124, 554-559. [CrossRef]

75. Duncker, D.; Haghikia, A.; König, T.; Hohmann, S.; Gutleben, K.-J.; Westenfeld, R.; Oswald, H.; Klein, H.; Bauersachs, J.; Hilfiker-Kleiner, D.; et al. Risk for ventricular fibrillation in peripartum cardiomyopathy with severely reduced left ventricular function-value of the wearable cardioverter/defibrillator. Eur. J. Heart Fail. 2014, 16, 1331-1336. [CrossRef]

76. Sliwa, K.; Petrie, M.C.; Hilfiker-Kleiner, D.; Mebazaa, A.; Jackson, A.; Johnson, M.R.; van der Meer, P.; Mbakwem, A.; Bauersachs, J. Long-term prognosis, subsequent pregnancy, contraception and overall management of peripartum car-diomyopathy: Practical guidance paper from the Heart Failure Association of the European Society of Cardiology Study Group on Peripartum Cardiomyopathy. Eur. J. Heart Fail. 2018, 20, 951-962. [CrossRef]

77. Lin, G.; A Nishimura, R.; Gersh, B.J.; Phil, D.; Ommen, S.R.; Ackerman, M.J.; A Brady, P. Device complications and inappropriate implantable cardioverter defibrillator shocks in patients with hypertrophic cardiomyopathy. Heart 2009, 95, 709-714. [CrossRef]

78. Sherrid, M.V.; Daubert, J.P. Risks and Challenges of Implantable Cardioverter-Defibrillators in Young Adults. Prog. Cardiovasc. Dis. 2008, 51, 237-263. [CrossRef]

79. Healy, C.A.; Carrillo, R.G. Wearable cardioverter-defibrillator for prevention of sudden cardiac death after in-fected implantable cardioverter-defibrillator removal: A cost-effectiveness evaluation. Heart Rhythm 2015, 12, 1565-1573. [CrossRef]

80. Franke, J.; Zugck, C.; Hochadel, M.; Hack, A.; Frankenstein, L.; Zhao, J.D.; Ehlermann, P.; Nelles, M.; Zeymer, U.; Winkler, R.; et al. Etiology-specific assessment of predictors of long-term survival in chronic systolic heart failure. IJC Heart Vasc. 2015, 7, 61-68. [CrossRef]

81. Le, K.Y.; Sohail, M.; Friedman, P.A.; Uslan, D.Z.; Cha, S.S.; Hayes, D.L.; Wilson, W.R.; Steckelberg, J.M.; Baddour, L.M. Impact of timing of device removal on mortality in patients with cardiovascular implantable electronic device infections. Heart Rhythm 2011, 8, 1678-1685. [CrossRef] [PubMed]

82. Maytin, M.; Jones, S.O.; Epstein, L.M. Long-Term Mortality After Transvenous Lead Extraction. Circ. Arrhythmia Electrophysiol. 2012, 5, 252-257. [CrossRef] [PubMed]

83. Bardy, G.H.; Lee, K.L.; Mark, D.; Poole, J.E.; Packer, D.L.; Boineau, R.; Domanski, M.; Troutman, C.; Anderson, J.; Johnson, G.; et al. Amiodarone or an Implantable Cardioverter-Defibrillator for Congestive Heart Failure. N. Engl. J. Med. 2005, 352, 225-237. [CrossRef] [PubMed]

84. Moss, A.J.; Hall, W.J.; Cannom, D.S.; Daubert, J.P.; Higgins, S.L.; Klein, H.; Levine, J.H.; Saksena, S.; Waldo, A.L.; Wilber, D.; et al. Improved Survival with an Implanted Defibrillator in Patients with Coronary Disease at High Risk for Ventricular Arrhythmia. N. Engl. J. Med. 1996, 335, 1933-1940. [CrossRef] [PubMed]

85. Moss, A.J.; Zareba, W.; Hall, W.J.; Klein, H.; Wilber, D.J.; Cannom, D.S.; Daubert, J.P.; Higgins, S.L.; Brown, M.W.; Andrews, M.L. Multicenter Automatic Defibrillator Implantation Trial II Investigators, Prophylactic implantation of a defibril-lator in patients with myocardial infarction and reduced ejection fraction. N. Engl. J. Med. 2002, 346, 877-883. [CrossRef]

86. Hohnloser, S.H.; Kuck, K.H.; Dorian, P.; Roberts, R.S.; Hampton, J.R.; Hatala, R.; Fain, E.; Gent, M.; Connolly, S.J. Prophylactic Use of an Implantable Cardioverter-Defibrillator after Acute Myocardial Infarction. N. Engl. J. Med. 2004, 351, 2481-2488. [CrossRef]

87. Kadish, A.; Dyer, A.; Daubert, J.P.; Quigg, R.; Estes, N.M.; Anderson, K.P.; Calkins, H.; Hoch, D.; Goldberger, J.; Shalaby, A.; et al. Prophylactic Defibrillator Implantation in Patients with Nonischemic Dilated Cardiomyopathy. N. Engl. J. Med. 2004, 350, 2151-2158. [CrossRef]

88. van Barreveld, M.; Verstraelen, T.E.; van Dessel, P.F.H.M.; Boersma, L.V.A.; Delnoy, P.P.H.M.; Tuinenburg, A.E.; Theuns, D.A.M.J.; van der Voort, P.H.; Kimman, G.-J.; Buskens, E.; et al. DO-IT Registry Investigators, Dutch Outcome in Implantable CardioverterDefibrillator Therapy: Implantable Cardiovert-er-Defibrillator-Related Complications in a Contemporary Primary Prevention Cohort. J. Am. Heart Assoc. 2021, 10, e018063. [CrossRef] 
89. Patel, N.J.; Edla, S.; Deshmukh, A.; Nalluri, N.; Patel, N.; Agnihotri, K.; Patel, A.; Savani, C.; Patel, N.; Bhimani, R.; et al. Gender, Racial, and Health Insurance Differences in the Trend of Implantable Cardiovert-er-Defibrillator (ICD) Utilization: A United States Experience Over the Last Decade. Clin. Cardiol. 2016, 39, 63-71. [CrossRef]

90. Lozano, I.F.; Asensi, J.O.; Rodríguez, J.A. Spanish Implantable Cardioverter-defibrillator Registry. 17th Official Report of the Heart Rhythm Association of the Spanish Society of Cardiology (2020). Rev. Esp. Cardiol. 2021, 74, 971-982. [CrossRef]

91. Bauersachs, J.; Arrigo, M.; Hilfiker-Kleiner, D.; Veltmann, C.; Coats, A.J.S.; Crespo-Leiro, M.G.; De Boer, R.A.; Van Der Meer, P.; Maack, C.; Mouquet, F.; et al. Current management of patients with severe acute peripartum cardiomyopathy: Practical guidance from the Heart Failure Association of the European Society of Cardiology Study Group on peripartum cardiomyopathy. Eur. J. Heart Fail. 2016, 18, 1096-1105. [CrossRef] [PubMed]

92. Clark, M.A.; Szymkiewicz, S.J.; Volosin, K. Mortality and Costs Associated with Wearable Cardiovert-er-defibrillators after Acute Myocardial Infarction: A Retrospective Cohort Analysis of Medicare Claims Data. J. Innov. Card Rhythm Manag. 2019, 10, 3866-3873. [CrossRef]

93. Buxton, M.; Caine, N.; Chase, D.; Connelly, D.; Grace, A.; Jackson, C.; Parkes, J.; Sharples, L. A review of the evi-dence on the effects and costs of implantable cardioverter defibrillator therapy in different patient groups, and modelling of cost-effectiveness and cost-utility for these groups in a UK context. Health Technol. Assess 2006, 10, iii-iv. [CrossRef] [PubMed]

94. Gandjour, A.; Dipl-Ges-Ök, A.H.; Adarkwah, C.C. Cost-effectiveness of implantable defibrillators after myocardial infarction based on 8-year follow-up data (MADIT II). Value Health 2011, 14, 812-817. [CrossRef] [PubMed]

95. Wilkoff, B.L.; Love, C.J.; Byrd, C.L.; Bongiorni, M.G.; Carrillo, R.G.; Crossley, G.H.; Epstein, L.M.; Friedman, R.A.; Kennergren, C.E.; Mitkowski, P.; et al. Heart Rhythm Society, American Heart Association, Transvenous lead extraction: Heart Rhythm Society expert consensus on facilities, training, indications, and patient man-agement: This document was endorsed by the American Heart Association (AHA). Heart Rhythm 2009, 6, 1085-1104. [CrossRef] [PubMed]

96. Reek, S.; Burri, H.; Roberts, P.R.; Perings, C.; Epstein, A.E.; Klein, H.U.; Lip, G.; Gorenek, B.; Sticherling, C.; Fauchier, L.; et al. The wearable cardioverter-defibrillator: Current technology and evolving indications. Europace 2016, 19, 335-345. [CrossRef]

97. Boriani, G.; Mantovani, L.G.; Cortesi, P.A.; De Ponti, R.; D’Onofrio, A.; Arena, G.; Curnis, A.; Forleo, G.; Guerra, F.; Porcu, M.; et al. Cost-minimization analysis of a wearable cardioverter defibrillator in adult patients un-dergoing ICD explant procedures: Clinical and economic implications. Clin. Cardiol. 2021, 44, 1497-1505. [CrossRef] [PubMed] 